\title{
HUBUNGAN TINGKAT PENGETAHUAN LINGKUNGAN HIDUP DENGAN SIKAP PEDULI LINGKUNGAN SISWA
}

\author{
Bonita Simarmata $^{1^{*}}$, Abdul Hakim Daulae $^{2}$, Raihana $^{3}$ \\ ${ }^{1,2}$ Program Studi Pendidikan Biologi, FMIPA, Universitas Negeri Medan, Jl. Willem Iskandar Psr. V, \\ Medan Estate, Medan, Indonesia, 20221 \\ ${ }^{3}$ SMA Negeri 14 Medan, Jalan Pelajar Ujung, Kelurahan Binjai, Medan Denai, \\ Kota Medan, Indonesia, 20228 \\ *E-mail : Simarmatabonita29@gmail.com
}

\begin{abstract}
ABSTRAK
Penelitian ini bertujuan melihat hubungan dan kontribusi antara tingkat pengetahuan lingkungan hidup dengan sikap peduli lingkungan siswa di SMA Negeri 14 Medan. Penelitian ini dilakukan terhadap seluruh siswa kelas X yang terdiri dari 10 kelas, dengan jumlah populasi 360 orang dan sampel 130 orang siswa. Jenis penelitian ini adalah penelitian deskriptif dengan teknik korelasi. Teknik pengampilan sampel dilakukan dengan cara Random Sampling. Instrumen penelitian yang digunakan adalah tes pengetahuan lingkungan, angket sikap peduli lingkungan, lembar observasi dan wawancara. Hasil Penelitian menunjukkan bahwa nilai korelasi yang terbentuk dari tingkat pengetahuan lingkungan hidup siswa dengan sikap peduli lingkungan siswa adalah sebesar 0,327 (rendah) dengan kontribusi sebesar 10,7 \% dan analisis regresi menunjukkan persamaan regresi $\hat{Y}=81,557+0,157 X$. Dari hasil perhitungan diperoleh $t_{\text {hitung }} 3,915>t_{\text {tabel }} 1,9978$. Hal ini mengindikasikan bahwa $\mathrm{H}_{\mathrm{a}}$ diterima dan $\mathrm{H}_{0}$ ditolak, dengan kata lain ada hubungan yang signifikan antara tingkat pengetahuan lingkungan hidup dengan sikap peduli lingkungan siswa di SMA Negeri 14 Medan.
\end{abstract}

Kata kunci: Lingkungan Hidup, Pengetahuan, Sikap

ABSTRACT

This study aims to look at the relationship and contribution between the level of environmental knowledge and environmental care. This research was conducted on all class $X$ students consisting of 10 classes, with a population of 360 people and a sample of 130 students. This type of research is descriptive research with correlation techniques. Sampling technique is done by Random Sampling. The research instruments used were environmental knowledge tests, environmental care attitude questionnaires, observation sheets, and interviews. The results showed that the correlation value between the level of environmental knowledge of students with a caring attitude towards students was 0.327 (low) with a contribution of $10.7 \%$ and regression analysis showed a regression equation $\hat{Y}=81.557+0.157 \mathrm{X}$. From the calculation results obtained $\mathrm{t}$ count $3,915>\mathrm{t}$ table 1.9978. This indicates that $\mathrm{Ha}$ is accepted and $\mathrm{HO}$ is rejected, in other words, there is a significant relationship between the level of environmental knowledge and the environmentally caring attitude of students in Medan 14 High School.

Keywords: Attitude, Environment, Knowledge 
JURNAL PELITA PENDIDIKAN VOL. 6 NO. 4

Simarmata, B., Daulae, A.H, \& Raihana

Halaman : 204-210

\section{PENDAHULUAN}

Isu global tentang lingkungan menjadi hal yang sangat sering terdengar pada saat ini dimana banyak sekali kerusakan lingkungan yang terjadi akibat pembalakan liar dan penggunaan sumber daya alam secara berlebihan tanpa ada konservasi yang berkelanjutan, terjadinya peningkatan pemanasan global, dan menurunnya kualitas ekosistem alam. Hal ini disebabkan oleh kurangnya pengetahuan dan kepedulian terhadap lingkungan. Akibatnya lingkungan mengalami kerusakan yang juga menjadi ancaman bagi masyarakat dunia, misalnya banjir, tanah longsor, polusi, habisnya sumber air (Azmi, 2017).

Kepedulian terhadap lingkungan dipengaruhi oleh pengetahuan lingkungan. Hal ini diharapkan dapat menjadi rujukan yang benar dalam menjaga kelestarian alam serta memecahkan masalah lingkungan yang dihadapinya. Salah satu perilaku yang perlu dikembangkan bagi generasi muda bangsa adalah perilaku peduli lingkungan dan tanggung jawab terhadap masalah kerusakan lingkungan hidup yang terjadi di lingkungan (Ardianti, 2017).

Masalah lingkungan hidup yang terjadi saat ini, baik dari lingkungan global maupun lingkup nasional, sebagian besar bersumber dari perilaku manusia. Sebuah jurnal mengenai lingkungan hidup yang ditulis oleh (Halder, 2012) mengatakan bahwa empat puluh tahun terakhir telah keluar pengakuan internasional bahwa tantangan yang berkaitan dengan degradasi lingkungan dan pembangunan berkelanjutan memiliki implikasi penting yang berhubungan dengan pendidikan dan sekolah. Yang artinya lingkungan hidup berpengaruh besar terhadap ketercapaian tujuan pendidikan.

Adapun upaya yang telah dilakukan oleh Kementerian Lingkungan Hidup terhadap pentingnya pendidikan lingkungan hidup melalui sekolah langsung ialah adanya Sekolah Adiwiyata. Pendidikan lingkungan adalah upaya mengubah perilaku dan sikap yang dilakukan oleh masyarakat yang bertujuan untuk meningkatkan pengetahuan, keterampilan, dan kesadaran masyarakat tentang nilai-nilai dan isu lingkungan untuk kepentingan generasi sekarang dan generasi selanjutnya. Siswa sebagai salah satu subjek pendidikan memiliki peran dalam menjaga, melestarikan dan memecahkan masalah lingkungan. Maka siswa harus dididik untuk mengetahui, menyadari, dan meyakini akan adanya
pISSN : 2338 - 3003

elSSN : $2502-3217$

pendidikan ini memberikan dampak pada bertambahnya pengetahuan dan keterampilan serta akan menolong dalam pembentukan sikap dan perilaku yang positif (Ardianti, 2017).

Permasalahan lingkungan hidup berkaitan dengan pemahaman, sikap dan perilaku bersifat subjektif, karena masing-masing siswa mempunyai tingkat pengetahuan lingkungan yang berbeda. Persepsi siswa terhadap kondisi lingkungan yang ada akan berbeda pula sesuai dengan pemahaman dan kesadarannya. Pada saat ini Indonesia memerlukan manusia-manusia yang sadar terhadap lingkungan, yaitu manusia yang sudah memahami dan menerapkan sikap dan perilaku peduli lingkungan serta menerapkan prinsip-prinsip ekologi dan etika lingkungan.

Beberapa hasil penelitian tentang hubungan pengetahuan lingkungan hidup dengan sikap peduli lingkungan antara lain: Sirait (2012) menemukan bahwa terdapat hubungan yang signifikan antara tingkat pengetahuan dan perilaku mencintai lingkungan siswa, artinya semakin tinggi nilai pengetahuan lingkungan hidup maka akan semakin tinggi juga nilai perilaku mencintai lingkungan siswa.Sebaliknya semakin rendah nilai pengetahuan lingkungan hidup maka akan semakin rendah juga perilaku mencintai lingkungan siswa. Azhar (2015) menemukan bahwa terdapat hubungan yang positif yang cukup signifikan dan mendekati signifikan antara pengetahuan lingkungan hidup dengan sikap menjaga kelestarian lingkungan hidup. Apabila nilai pengetahuan lingkungan hidup mengalami kenaikan maka nilai sikap menjaga kelestarian lingkungan juga akan ikut meningkat. Sebaliknya jika nilai pengetahuan lingkungan hidup mengalami penurunan maka nilai sikap menjaga kelestarian lingkungan juga akan ikut menurun.

Sekolah SMA Negeri 14 Medan merupakan sekolah yang hakikatnya ikut serta untuk menjaga kebersihan lingkungan. Terlihat dari sarana dan prasarana yang disediakan sekolah untuk menjaga kebersihan lingkungan. Di sebelah sekolah terdapat sungai, dan di depan sekolah terdapat pemukiman warga. Hal ini menunjukkan bahwa keadaan lingkungan luar sekolah sangat berpengaruh terhadap lingkungan di dalam sekolah .

Berdasarkan hasil observasi yang telah dilakukan oleh peneliti pada Januari 2018 di SMA Negeri 14 Medan, ditemukan masih terdapat siswa yang mencoret-coret meja, kursi, dinding sekolah dengan menggunakan pulpen, membawa makanan dari 
kantin ke dalam kelas dan menjadikan laci meja sebagai tempat pembuangan sampah, tidak melaksanakan tugas piket kelas, kamar mandi siswa yang kotor dan bau kemudian sampah bungkus makanan yang berserakan di depan kamar mandi. Sikap membuang sampah sembarangan ini seolaholah menjadi sebuah kebiasaan.

Permasalahan inilah yang harus diatasi dengan menanamkan pengetahuan dan sikap untuk terus mencintai lingkungan. Menurut Amindrand (2013), jika orang-orang memiliki pengetahuan lebih tentang lingkungan dan isu-isu terkait, mereka akan menjadi lebih sadar lingkungan dan masalah-masalahnya. Dengan demikian lebih termotivasi untuk bertindak ke arah lingkungan dengan cara yang lebih bertanggung jawab. Memasukkan nilai-nilai kesadaran lingkungan hidup pada setiap siswa melalui pelajaran maupun dengan membangun sikap-sikap peduli lingkungan merupakan hal yang utama.

\section{METODE PENELITIAN}

Populasi dalam penelitian ini adalah seluruh siswa kelas X SMA Negeri 14 Medan dengan jumlah 360 orang yang terdiri dari 10 kelas. Adapun yang menjadi sampel penelitian ini adalah kelas X MIPA 1, $X$ MIPA 2, X MIPA 3, dan X MIPA 4 yang terdiri dari 130 Siswa.

Instrumen dalam penelitian ini adalah tes pengetahuan lingkungan hidup, angket sikap peduli lingkungan siswa, lembar observasi, dan lembar wawancara. Jenis penelitian ini adalah penelitian korelasional yang bertujuan untuk menemukan ada tidaknya hubungan dan apabila ada, berapa eratnya hubungan serta berarti tidak hubungan itu.

Teknik analisis data yang dilakukan teknik korelasi product moment yang digunakan untuk mencari korelasi antar variabel bebas $(X)$ dengan variabel terikat (Y). Analisis korelasi antar variabel dilakukan pada penelitian ini yaitu korelasi pengetahuan lingkungan hidup dengan sikap peduli siswa.

\section{HASIL PENELITIAN}

\section{Tingkat Pengetahuan Lingkungan Siswa}

Berdasarkan data tes tingkat pengetahuan lingkungan yang diperoleh dari hasil penelitian dengan jumlah responden 130 diperoleh rata-rata $(\bar{x})=50,98$ dan standar deviasi $($ SD) $=16,51$.
Distribusi frekuensi tingkat pengetahuan lingkungan siswa dapat dilihat pada tabel di bawah ini.

Tabel 1.

Distribusi Frekuensi Tingkat Pengetahuan Lingkungan Siswa

\begin{tabular}{ccc}
\hline Kelas & Interval Nilai & Frekuensi \\
\hline 1 & $12-20$ & 7 \\
2 & $21-29$ & 7 \\
3 & $30-38$ & 15 \\
4 & $39-47$ & 23 \\
5 & $48-54$ & 14 \\
6 & $55-63$ & 24 \\
7 & $64-72$ & 29 \\
8 & $73-80$ & 11 \\
\hline \multicolumn{2}{c}{ Jumlah }
\end{tabular}

Sikap Peduli Lingkungan Siswa

Berdasarkan data yang diperoleh dari hasil penelitian dengan jumlah responden 130 diperoleh rata-rata $(\bar{x})=89,56$ dan standar deviasi $(S D)=7,29$. Distribusi frekuensi sikap peduli lingkungan siswa dapat dilihat pada tabel dibawah ini:

Tabel 2. Distribusi Frekuensi Sikap Peduli Lingkungan

\begin{tabular}{ccc} 
& Siswa & \\
\hline Kelas & Interval & Frekuensi \\
\hline 1 & $70-73$ & 3 \\
2 & $74-77$ & 8 \\
3 & $78-81$ & 17 \\
4 & $82-85$ & 10 \\
5 & $86-89$ & 18 \\
6 & $90-93$ & 10 \\
7 & $94-97$ & 46 \\
8 & $98-100$ & 18 \\
\hline \multicolumn{3}{c}{ Jumlah }
\end{tabular}

Uji Persamaan Regresi, dan Keberartian Regresi Linear

Untuk kelinearan persamaan regresi, diperoleh $F_{\text {hitung }}=1,141$, kemudian dikonsultasikan dengan $F_{\text {tabel }}$ pada $\alpha=0,05$ dengan $\mathrm{dk}$ pembilang $=16 \mathrm{dan} \mathrm{dk}$ penyebut $=112$, diperoleh $F_{\text {tabel }}=3,82$. Sehingga diperoleh $F_{\text {hitung }}<F_{\text {tabel }}$ yaitu $1,141<3,82$ sehingga dapat disimpulkan bahwa persamaan regresi $\hat{Y}=$ $81,557+0,157$ adalah linear. 


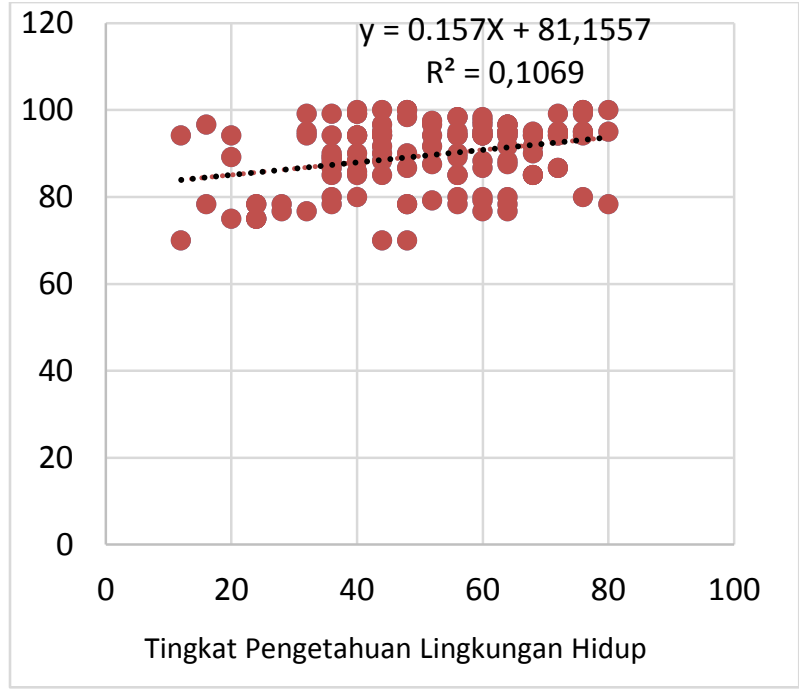

Gambar 1. Diagram Persamaan Regresi

Selanjutnya untuk keberartian regresi dengan mengkonsultasikan $F_{\text {hitung }}$ dengan $F_{\text {tabel }}$ pada $\alpha=0,05$ dengan $\mathrm{dk}$ pembilang $=1 \mathrm{dan} \mathrm{dk}$ penyebut $=$ 128 , diperoleh $F_{\text {tabel }}=3,36$ sehingga diperoleh $F$ hitung $>F$ tabel yaitu 15,34>3,36 yang berarti regresi $X$ dan $Y$ bersifat nyata (berarti). Untuk lebih jelasnya persamaan regresi dapat dilihat pada diagram di atas (Gambar 4.3).

Dari gambar diagram tersebut (Gambar 1) dilihat bahwa persamaan regresi berada pada garis $\hat{\mathrm{Y}}=81,557+0,157$ yang mempunyai koefisien determinasi $\left(R^{2}\right)$ sebesar 0,1069. Maka persamaan $\hat{Y}$ mengartikan $\hat{Y}$ fungsi $X$, artinya bila $\hat{Y}$ adalah tingkat pengetahuan dan $X$ adalah sikap peduli lingkungan, maka nilai sikap $(\hat{Y})$ bergantung pada tingkat pengetahuan lingkungan hidup (X).

Hasil uji normalitas dengan menggunakan uji Lilliefors diperoleh $L_{\text {hitunng }}<L_{\text {tabel }}$ yaitu $0,0193<$ 0,0777 dan $0,0662<0,0777$ sehingga dapat disimpulkan bahwa data pada variabel $X$ dan $Y$ berdistribusi normal.

Hasil uji Homogenitas dengan menggunakan uji Bartlett diperoleh $\mathrm{X}^{2}$ hitung $<\mathrm{X}^{2}$ tabel atau $64,072<156$, 507 , dengan demikian disimpulkan bahwa data homogen.

Hasil Uji Koefisien Korelasi diperoleh $r_{x y}=0,327$ .Karena $r_{\text {hitung }}=0,327>r_{\text {tabel }}=0,176$, maka terdapat hubungan korelasi tetapi hubungannya lemah atau rendah. Sehingga dapat disimpulkan bahwa terdapat hubungan antara tingkat pengetahuan lingkungan dan sikap peduli lingkungan siswa di SMA Negeri 14 Medan.
Berdasarkan hasil perhitungan pada Uji Hipotesis diperoleh $t_{\text {hitung }}(3,915)>t_{\text {tabel }}(1,978)$ sehingga dapat disimpulkan bahwa hipotesis alternatif ( $\mathrm{Ha}$ ) dalam penelitian ini diterima sekaligus menolak hipotesis nihil $\left(\mathrm{H}_{0}\right)$ dengan kata lain terdapat hubungan yang signifikan antara tingkat pengetahuan lingkungan dengan sikap peduli lingkungan siswa di SMA Negeri 14 Medan.

\section{Data Hasil Observasi Sikap Peduli Lingkungan}

Observasi dilakukan oleh observer secara langsung kepada seluruh sampel, yakni kelas X MIPA 1, X MIPA 2, X MIPA 3, dan X MIPA 4. Observasi yang dilakukan kepada siswa kelas X SMA Negeri 14 Medan untuk mengetahui sikap peduli lingkungan siswa. Berdasarkan hasil observasi sikap peduli lingkungan siswa diperoleh presentasi nilai rata-rata hasil observasi sesuai pada lembar observasi yang sudah ditentukan rubrik penskorannya dapat dilihat pada Tabel 4.5.

Tabel 3. Hasil Observasi Sikap Peduli Lingkungan

\begin{tabular}{ccc}
\hline Pernyataan & Rentang Nilai & Keterangan \\
\hline 1 & 89 & Sangat Baik \\
2 & 35,33 & Kurang \\
3 & 51,5 & Cukup \\
4 & 38,25 & Kurang \\
5 & 49,00 & Cukup \\
6 & 63,75 & Baik \\
7 & 39,5 & Kurang \\
8 & 67,33 & Baik \\
9 & 93,5 & Sangat Baik \\
10 & 93,5 & Sangat Baik \\
\hline
\end{tabular}

Data Hasil Wawancara Sikap Peduli Lingkungan Siswa

Dari hasil wawancara dengan 3 responden di SMA Negeri 14 Medan, ternyata terdapat beberapa faktor yang dapat mempengaruhi tingkat pengetahuan dan sikap peduli lingkungan siswa yaitu antara lain sarana prasarana dan sanksi dari pihak sekolah kepada siswa. Dimana sarana dan prasarana yang diberikan oleh sekolah sudah cukup memadai tetapi tidak dipergunakan sebaik-baiknya oleh siswa, kemudian pihak sekolah tidak memberikan sanksi atau peringatan kepada siswa jika tidak peduli terhadap lingkungan, misalnya jika tidak melakukan piket kelas, jumat bersih sehingga sikap peduli lingkungan siswa masih tergolong rendah. 
JURNAL PELITA PENDIDIKAN VOL. 6 NO. 4

Simarmata, B., Daulae, A.H, \& Raihana

Halaman : 204-210

\section{PEMBAHASAN}

Hubungan Tingkat Pengetahuan Lingkungan Hidup dengan Sikap Peduli Lingkungan Siswa

Tingkat pengetahuan lingkungan hidup siswa memiliki hubungan berkorelasi rendah dengan sikap peduli lingkungan siswa Kelas X SMA Negeri 14 Medan. Dengan besar koefisien korelasi $\left(r_{\mathrm{xy}}\right)$ sebesar 0,327. Hubungan ini termasuk dalam kategori rendah. Hal ini dilihat dari rata-rata nilai tingkat pengetahuan lingkungan hidup siswa. Siswa yang memiliki nilai pengetahuan lingkungan yang tinggi, maka sikap peduli lingkungannya akan baik. Begitu juga sebaliknya, siswa yang memiliki nilai pengetahuan lingkungan yang rendah memiliki sikap peduli lingkungan yang rendah.

Dari hasil penelitian yang dilakukan tingkat pengetahuan lingkungan hidup siswa tergolong dalam kategori cukup, hai ini dapat dilihat dari nilai rata-rata yang diperoleh sebesar 50,98 yang berada pada kelompok nilai 46-63. Pada lampiran 16 diketahui bahwa interval nilai pengetahuan lingkungan siswa berkisar dari 12 hingga 80, dimana siswa yang mendapat nilai tertinggi yaitu 80 hanya 3 orang siswa dan yang memperoleh nilai terendah yaitu 12 ada 2 orang siswa. Sedangkan sikap peduli lingkungan siswa di SMA Negeri 14 Medan berada pada kategori cukup baik. Hal ini dapat dilihat pada nilai rata-rata sikap peduli lingkungan siswa yang diperoleh sebesar 89,56 berada pada kelompok 8592,5 . Berdasarkan lampiran 16 bahwa interval nilai sikap peduli lingkungan siswa berkisar 100 hingga 70, dimana siswa yang mendapat nilai tertinggi yaitu 100 ada 7 orang siswa, sedangkan yang memperoleh nilai terendah yaitu 70 ada 3 orang siswa.

Hasil penelitian ini didukung oleh hasil observasi yang telah dilakukan di kelas X SMA Negeri 14 Medan (Lampiran 5), sikap peduli lingkungan siswa tergolong dalam kategori kurang, dilihat dari masih banyak siswa yang mencoret-coret meja dan dinding kelas, siswa tidak memungut sampah yang berserakan dan membuang sampah ke dalam laci meja, kantin sekolah yang kotor disebabkan karena kurangnya kesadaran siswa untuk membuang sampah pada tempatnya, dan tidak bekerja sama dalam melaksanakan piket kelas.

Berdasarkan hasil wawancara yang telah dilakukan kepada siswa kelas X SMA Negeri 14 Medan (Lampiran 6), untuk mendukung sikap peduli lingkungan siswa tersebut, dipengaruhi oleh kesadaran dari diri masing-masing. Selain itu faktor-
pISSN : 2338 - 3003

eISSN : 2502 - 3217

faktor yang mempengaruhi sikap peduli lingkungan dipengaruhi oleh sarana dan prasarana yang kurang memadai dan tidak adanya sanksi yang diberikan oleh sekolah jika tidak melakukan piket dan kebersihan kelas sehingga mengakibatkan kurangnya sikap peduli lingkungan siswa. Faktor-faktor inilah yang mampu mempengaruhi sikap siswa untuk menjaga lingkungannya.

Walaupun siswa sudah diberikan pengetahuan yang baik tentang lingkungan hidup (pelajaran biologi tentang pencemaran lingkungan ) dan program-program yang mendukung untuk melestarikan lingkungan, namun siswa tersebut tidak menunjukkan sikap peduli lingkungan yang baik. Hal ini didukung oleh penelitian yang dilakukan oleh Aminrad (2013), bahwa ada hubungan yang tinggi antara kesadaran dan sikap tentang lingkungan sementara hubungan antara kesadaran dan pengetahuannya lemah, dan untuk hubungan pengetahuan dan sikap tentang lingkungan adalah lemah. Hal ini menjelaskan bahwa siswa dengan kesadaran yang tinggi maka akan memiliki sikap peduli lingkungan yang tinggi, tetapi tidak bergantung pada pengetahuan. Juga didukung oleh penelitian oleh Sali (2015), bahwa terdapat hubungan lemah antara sikap terhadap lingkungan dan pengetahuan lingkungan.

Kontribusi Tingkat Pengetahuan Siswa Tentang Lingkungan Hidup Dengan Sikap Peduli Lingkungan

Hasil perhitungan diperoleh bahwa besarnya kontribusi yang diberikan oleh tingkat pengetahuan terhadap sikap peduli lingkungan siswa adalah sebesar 10,7 \% yang tergolong dalam kategori rendah. Berdasarkan skor rata-rata pengetahuan lingkungan, semakin tingginya pengetahuan dan sikap yang respinsif akan memberikan pengaruh terhadap wawasan dalam pengelolaan lingkungan, karena didukung oleh pengetahuan, serta memahami pengelolaan lingkungan yang bersih dan sehat, sehingga untuk peningkatan hidup bersih dan sehat dapat terwujud, kemudian adanya tanggung jawab karena menyadari bahwa hidup bersih dan sehat sangat didambakan oleh setiap manusia, serta adanya keterampilan dalam pengelolaan lingkungan dan sikap yang selalu respon terhadap lingkungan juga terbentuknya hasrat untuk membimbing keluarga agar selalu hidup bersih dan sehat (Munawar, 2014).

Hal ini menunjukkan bahwa tingkat pengetahuan lingkungan hidup siswa memiliki 
kontribusi (pengaruh) dalam menentukan sikap peduli lingkungan siswa . Sehingga dapat disimpulkan bahwa tingkat pengetahuan lingkungan hidup merupakan salah satu faktor yang menentukan sikap peduli lingkungan siswa. Sisanya dipengaruhi oleh faktor - faktor lain yang dianggap mampu mempengaruhi sikap peduli lingkungan siswa. Seperti yang telah dikemukakan oleh Azwar (2015), bahwa faktor - faktor yang mempengaruhi pembentukan sikap adalah pengalaman pribadi, orang lain yang dianggap penting, media massa, institusi atau lembaga pendidikan, dan lembaga agama serta faktor emosi dalam diri. Adapun faktor lain yang mempengaruhinya berdasarkan hasil wawancara dengan responden yaitu karena sarana dan prasarana yang kurang memadai (tidak dirawat dan digunakan dengan baik), dan tidak adanya sanksi yang diberikan oleh sekolah jika tidak melakukan piket dan kebersihan kelas sehingga mengakibatkan kurangnya sikap peduli lingkungan siswa. Faktor-faktor inilah yang mampu mempengaruhi sikap siswa untuk menjaga lingkungannya.

Guru juga berperan penting terhadap keberhasilan siswa untuk peduli terhadap lingkungan, dimana guru harus memberikan arahan dan bimbingan yang baik kepada siswa tentang hal positif untuk menjaga, melestarikan, dan peduli terhadap lingkungan nya. Hal ini di dukung oleh penelitian Sali (2015), yang mengatakan bahwa guru yang tidak peduli dengan masalah lingkungan, yang tidak memiliki pengetahuan dan budaya ekologi yang cukup, tidak memiliki latar belakang pengetahuan yang mendalam, serta tidak dilengkapi dengan pengalaman yang luas dan terampil. Maka akan gagal sebagai model untuk mendidik siswasiswanya dan akan mengalami kesulitan dalam mencapai tujuan pendidikan lingkungan.

\section{KESIMPULAN}

Terdapat hubungan antara tingkat pengetahuan lingkungan hidup dengan sikap peduli lingkungan siswa Kelas X SMA Negeri 14 Medan. Dengan nilai koefisien korelasi $\left(r_{x y}\right)$ sebesar 0,327 yang berada pada kategori rendah.

Kontribusi tingkat pengetahuan lingkungan hidup dengan sikap peduli lingkungan siswa Kelas $X$ SMA Negeri 14 Medan adalah sebesar 10,7 \%.

\section{UCAPAN TERIMA KASIH}

Penulis mengucapkan terima kasih kepada staf dan para dosen FMIPA Pendidikan Biologi yang telah banyak membantu dan memberikan arahan dalam penyelesaian penelitian saya ini.

\section{DAFTAR PUSTAKA}

Aminrad, Z., Zarina, S., dan Hadi, S, Relationship Between Awareness Knowledge, And attitude Towards Environmental Education Among Secondary School Students In Malaysia, World Applied Sciences Journal. 22 (9): 1326 - 1333. 2013.

Ardianti, D., Wanabuliandari, S., dan Rahardjo, S., Peningkatan Perilaku Peduli Lingkungan dan Tanggung Jawab Siswa Melalui Model

Ejas Dengan Pendekatan Science Edutainment, Jurnal Ilmiah Pendidikan Dasar, 4 (1): 1-7. 2017.

Azmi, Fadilla., dan Elfyetti., Analisis Sikap Peduli Lingkungan Melalui Program Adiwiyata di SMA Negeri 1 Medan, Jurnal geografi, 9 (2) : 125132. 2017.

Azhar., Basyir, D., dan Alfitri., Hubungan Pengetahuan dan Etika Lingkungan

Dengan Sikap dan Perilaku Menjaga Kelestarian Lingkungan, Jurnal IImu lingkungan, 13 (1):36-41. 2015.

Lusty,C., dan Maisayaroh, K., Peran Warga Sekolah Dalam Penerapan Pendidikan Lingkungan Hidup, Jurnal Menajemen Pendidikan, 25 (5): 454-459. 2012.

Sali, G., Korukcu, O., dan Akyol, A., Research On The Environtmental KnowledgeAnd Environmental Awareness of Preschool Teachers European Journal of Researh On Education, 3 (1) : 69-79. 2015.

Silitonga., dan Jenny, E., Hubungan Pengetahuan Lingkungan, Kemampuan Berpikir Kritis, Sikap IImiah dengan Kepedulian Lingkungan Siswa SMA Negeri Se-Kota Rantau Prapat, Thesis, Univeritas Negeri Medan. 2016.

Sirait, Nelly., dan Florida., Hubungan Tingkat Pengetahuan dan Kemampuan Berpikir Kritis Terhadap Perilaku mencintai lingkungan siswa

SMA Negeri Se-Kota Medan, Thesis, Universitas Negeri Medan. 2012. 
Thompson., Ecosentric And Antrhoposentric attitude toward environment, Jurnal of environment Psycolog. (14):149-157. 1994.

Triwardani, R., Pembudayaan Karakter Peduli Lingkungan Melalui Kegiatan Bank Sampah di Desa Duwet Kecamatan Bendo, Kajian moral dan Kewarganegaraan, 1(3): 471-483.2013.

Wawan, A., dan Dewi, M., Teori Dan Pengukuran Pengetahuan, Sikap, Dan Perilaku

Manusia, Penerbit Nuha medika, Yogyakarta. 2014.

Yuslina., Hubungan Pengetahuan Lingkungan Hidup dan Sikap Serta Perilaku Mahasiswa FKIP UISU Terhadap Kesadaran Dalam Pengelolaan Lingkungan Hidup di Kita Medan, Thesis, Universitas Negeri Medan. 2013. 